\title{
Reflections on disruptive energy innovation in urban retrofitting: methodology, practice and policy
}

Article

Accepted Version

Creative Commons: Attribution-Noncommercial-No Derivative Works 4.0

Dixon, T., Lannon, S. and Eames, M. (2018) Reflections on disruptive energy innovation in urban retrofitting: methodology, practice and policy. Energy Research \& Social Science, 37. pp. 255-259. ISSN 2214-6296 doi:

https://doi.org/10.1016/j.erss.2017.10.009 Available at https://centaur.reading.ac.uk/73597/

It is advisable to refer to the publisher's version if you intend to cite from the work. See Guidance on citing.

Published version at: http://www.sciencedirect.com/science/article/pii/S2214629617303365

To link to this article DOI: http://dx.doi.org/10.1016/j.erss.2017.10.009

Publisher: Elsevier

All outputs in CentAUR are protected by Intellectual Property Rights law, including copyright law. Copyright and IPR is retained by the creators or other copyright holders. Terms and conditions for use of this material are defined in the End User Agreement.

www.reading.ac.uk/centaur 
Central Archive at the University of Reading

Reading's research outputs online 
Reflections on disruptive energy innovation in urban retrofitting: methodology, practice and policy

Tim Dixon, Simon Lannon and Malcolm Eames

Tim Dixon, School of the Built Environment, University of Reading, UK

Simon Lannon, Welsh School of Architecture, Cardiff University

Malcolm Eames (TBC)

Corresponding author: Tim Dixon

Professor Tim Dixon

Chair in Sustainable Futures in the Built Environment

Co-Director of TSBE Centre

School of the Built Environment

University of Reading

Chancellor's Building

Chancellor's Way

Whiteknights

Reading

RG6 6DF

E: t.j.dixon@reading.ac.uk

$\mathrm{T}: \underline{+44(0) 1183787181}$ 


\title{
Special Issue of Energy Research and Social Science (ERSS)
}

on Disruptive Innovation and Energy Transformation

\begin{abstract}
Reflections on disruptive energy innovation in urban retrofitting: methodology, practice and policy
\end{abstract}

\subsection{The challenge of urban retrofit}

We live in an urban age. A majority of the world's population (3.9b or $54 \%$ ) lives in cities and this is set to grow to $66 \%$ by 2050 (UN, 2014). On the one hand, this urban growth provides us with huge opportunities, because cities can act as centres of knowledge and innovation, enterprise and jobs, and as the focus for creating economies of scale in rolling out new technologies. However, this can also provide us with big challenges, because as urbanisation continues rapidly it creates more greenhouse gas emissions, depletes resources, consumes more energy and can create socio-economic polarisation. Although 'cities' are only explicitly mentioned twice in the 2015 Paris Agreement on climate change, the agreement did give a strong mandate to the global buildings and construction sector to help keep global warming below 2 degrees $\mathrm{C}$, and to limit the increase even further to 1.5 degrees $\mathrm{C}$. Moreover, cities are implicitly seen as a strong focus for mitigation and adaptation activities to tackle climate change impacts (UN Habitat, 2016).

An important challenge is to be able to develop the knowledge, capacity and power for public bodies, businesses and other users in urban areas, particularly in the developed world, to systemically retrofit built environment and city infrastructure to respond to climate change, resource depletion and socio-environmental problems (Dixon et al, 2014a; Eames et al, 2017).

Indeed, over the last decade, the drive to 'retrofit' existing buildings and the built environment in response to the long-term challenges of climate change and resource constraints has gained increased discussion and debate (Dawson, 2007; Kelly, 2009; Eames et al, 2013). In the UK, the Climate Change Act and related $80 \%$ emissions reduction target for 2050 have focused considerable attention on the impact of the built environment in cities on greenhouse gas emissions. In the UK therefore, there is a strong focus on retrofitting existing buildings and infrastructure. Because building stock turnover in the UK is relatively sluggish, only about $1-2 \%$ of total building stock each year can be defined as 'new build' (Dixon, 2009; Stafford et al, 2011), and approximately $70 \%$ of total 2010 building stock is expected to still be standing in 2050 (Better Buildings Partnership, 2010).

The concept of 'retrofitting' has the literal meaning of 'adding (a component or accessory) to something that did not have it when manufactured' (Oxford English Dictionary), but the term has also often also been used synonymously in the built environment with terms such as 'refurbishment' or 'conversion' (Dixon, 2014a). At a city-scale, however, retrofit is seen as more comprehensive and wider in scope. For example, 'sustainable urban retrofitting' can be seen as the directed alteration of the fabric, forms or systems that comprise the built environment to improve water, energy and waste efficiencies (Eames, 2011).

Research on retrofitting in the built environment has traditionally focused on either individual buildings (or building components), or neighbourhood or district level, as opposed to city scale. However, we often think of this kind of large-scale transforming change in relation to 'what' is needed, and 'how' it can be implemented, without thinking about the way in which to address both together (Eames et al, 2013; Dixon et al, 2014: Hodson and Marvin, 2016). 
In this sense cities should not be seen as a 'blank canvas'. To implement the systematic change required, we need to consider cities as they exist today: as a complex mix of homes and businesses, and the product of many hundreds of years of evolution and growth. We also need to recognise that cities can become "locked" into patterns of resource use that can no longer be justified, and tried to find ways to change them, and to also respect their social, environmental and economic sustainability (Eames et al 2014a; Eames et al, 2017).

This means having a primary focus on understanding 'disruptive innovations' at city level, and combining this understanding within an urban transition framework. In this paper, we define what is meant by disruptive energy innovation. We then explore how an integrated urban foresight methodology can help us explore the socio-technical construction of such urban retrofit processes across multiple scales and domains. We conclude with a discussion of the practice and policy implications of this research perspective. 


\subsection{Disruptive energy innovations: definition and examples}

In the field of 'Technological Innovation Systems' (Dixon et al 2014b) innovations can be classified according to whether they are 'incremental', 'radical' or 'disruptive'.

Firstly, incremental innovations emerge from discoveries which happen in 'existing technology paradigms', but which do not affect them to any large extent (Foxon, 2003) (for example, in a wind turbine lengthening the blades to increase efficiency (Arundel, et al, 2011). In contrast, a 'radical', or "transformative' technology involves many more alterations to how things happen, and requires new knowledge which may not necessarily be 'disruptive' (for example, fuel injection for a car engine). On the other hand, a "disruptive" technology involves new knowledge to produce a way of doing something differently, but does not require a substantial change in regime (for example, replacing using biofuels instead of petrol would disrupt markets and business models based on existing petroleum, but would tend to have a lower impact on social practices (i.e. driving)) (Greenacre, et al, 2011, Arundel, et al, 2011, Bower and Christensen, 1995).

'Disruptive technology' is also used as a term in 'Disruptive Innovation Theory' (DIT) to describe a technological innovation that suddenly affects existing technologies or markets (Bower and Christensen, 1995, Yu and Hang, 2010). Christensen (2003) also distinguishes 'disruptive" technologies from 'sustaining' (or 'incremental') technologies. For example, 'sustaining' innovations in a core market result in an improved product which provides improved quality at a lower price, in contrast to 'disruptive' technologies, which occur more at the margins of markets which are already established.

Examples of disruptive technologies which could be considered to be part of the 'energy retrofit domain' include: (i) light emitting diode (LED lighting) as a replacement for incandescent lighting, and (ii) phase change materials (which have a high heat of fusion and latent heat properties) for energy storage and production. (Dixon et al, 2014b). Although these represent 'technological breakthroughs', they do not necessarily require wholesale regime change for them to succeed, and so can be seen as disruptive rather than radical.

Nonetheless, disruptive technologies can also impact on business models through increased competition in the utilities market (Parkinson, 2012 and Busnelli et al 2011, Dixon et al, 2014b). For example, utility profits may be reduced in highly-priced markets, where, for example, new technologies, such as renewables, can impact on electricity prices. However, disruptive technologies are by their nature hard to foresee and quite rare, and so they may be difficult to identify using conventional futures techniques (National Research Council of the National Academies, 2010; Dixon et al 2014b). Therefore, we need to develop combined (or 'hybrid') methodologies which can also provide clearer identification of innovations which are unpredictable and uncertain.

\subsection{Theoretical perspectives: an integrated urban foresight methodology}

Urban retrofitting tends to be complex, large scale and integrated and with a clear strategy in place (Living Cities, 2010). However, to respond to the challenges and complexities of urban retrofitting at scale means integrating the 'what' (for example, technical knowledge, targets, technology choices, costs) with the "how" of implementation (for example, institutional capacity, public engagement, and governance). Currently, there is still too much of a dichotomy between 
the "what" and "how" questions, which is characterised by fragmentation of disciplines; absence of suitable governance systems; and a failure in learning, and cross-transfer of that learning (May et al, 2010; Dixon et al, 2014a; Hodson and Marvin, 2016; Eames et al, 2017).

Urban retrofit transitions can be seen as complex, co-evolutionary, and characterised by nonlinear processes which draw upon a range of actors, and focus on different levels and dimensions over time, and this also draws form ideas and concepts anchored in systems, evolutionary and complexity theories (Geels et al 2008; Elzen et al, 2004: Kemp, et al, 2006; Eames et al, 2017).

Building upon these theoretical concepts, (and often focusing on case studies of energy, transport and food, for example), the multi-level perspective (MLP) has emerged as an important conceptual model for understanding large-scale socio-technical systems dynamics and change set against the interrelationship between niche, regime and landscape ('micro', 'meso', and 'macro') processes (Smith et al, 2010; Truffer and Coenen, 2012; Eames et al, 2013).

Urban retrofitting in the context of MLP can be seen as an interlocking system of innovation challenges, with a primary emphasis on (Eames et al, 2014; Eames et al, 2017) ${ }^{1}$ :

- Multi-scalar transitions: for example, building, neighbourhood, community, and city scales (i.e. 'integration across scales');

- Integrative perspectives on systems innovation over the long-term, which operate across sectors and levels. Here the concept of sociotechnical regime is used to identify particular urban retrofit 'regimes' (for example, housing, urban infrastructure and landuse regimes (Eames et al. 2013));

- The identification of sustaining and disruptive retrofit technologies which are important in understanding changes in the regime and niches brought about by technological innovation (Dixon et al, 2014b);

- Understanding retrofit as a 'co-evolutionary' and 'sociotechnical' process of change (Eames et al, 2013 and Hodson and Marvin, 2012).

The MLP can therefore be used to help conceptualise a stronger and more focused systemic approach, by avoiding 'piecemeal' and fragmented approaches to the problem. Drawing on 'transition management' frameworks, and theories related to the 'performative' roles of visions and expectations, offer a powerful set of tools (for example, 'backcasting' and' visioning' processes) for understanding future social and technical change (see for example, Eames et al, 2013; Dixon et al, 2014a; Eames et al, 2017).

\subsection{Methods for identifying disruptive energy innovations in urban retrofitting}

Previous research in urban retrofit has shown that two key techniques can be used to identify sustaining and disruptive technologies (Dixon et al, 2014b). These comprised: (i) participatory backcasting; and (ii) roadmapping, and were linked with a wider set of urban foresight methods (see Figure 1), which included a commissioned series of 'foresight'-based expert reviews authored by international experts.

\footnotetext{
${ }^{1}$ See McGrail and Gaziulusoy (2014) for an interesting comparison of EPSRC Retrofit 2050 and other urban transition research projects.
} 
Figure 1 Urban foresight methods and research design (Dixon et al, 2014b)

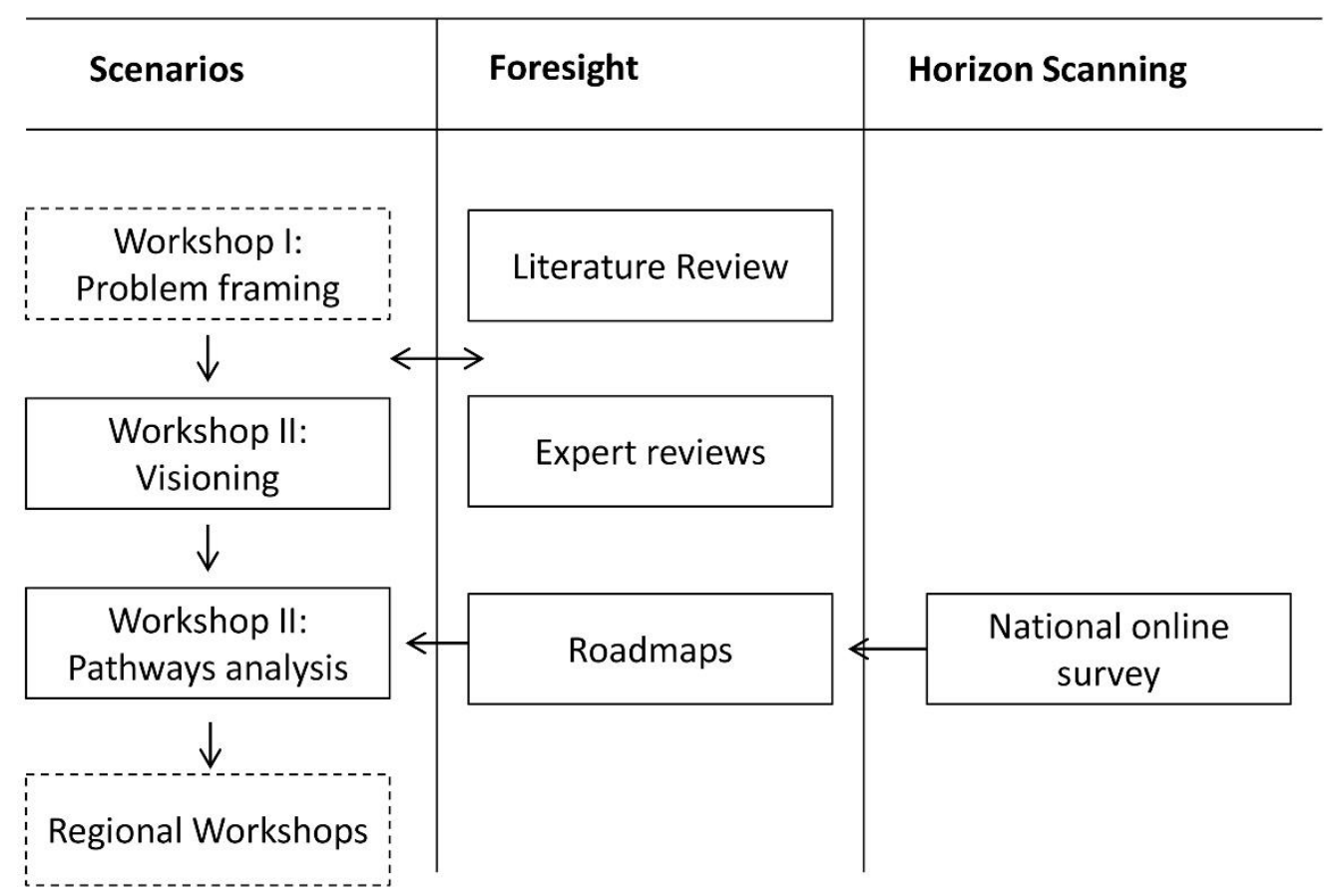

The research described in this short perspective (see Dixon et al, 2014b for further details) draws on key findings on disruptive technologies from Workshops II and III, national UK roadmaps and online survey work to help further identify sustaining and disruptive technologies. This process is described in detail in Eames et al (2013a; 2013b) and Dixon et al (2014a; 2014b).

The research adopted a participatory backcasting approach to develop a set of socio-technical transition urban retrofit scenarios which included the following:

- 'compact city' of intensive and efficient urban living

- 'smart networked city' hub within a networked, competitive society, and

- 'self-reliant green city' in harmony with nature.

Using these visions as a backdrop, and then linking the work with the other methods outlined in Figure 1, the research was able to identify and distinguish sustaining and disruptive technologies across different scales, and to ultimately set these within the socio-technical context of the urban retrofit visions. Table 1 identifies the key 'disruptive' and 'sustaining' energy technologies (according to the Christensen definition discussed above) which are expected by respondents to be important through to 2050 at building and neighbourhood scale and also at city scale (within the building domain in terms of building fabric and building services). 
Table 1 Examples of urban energy retrofit technologies (sustaining and disruptive) to 2050 across scales (adapted from Dixon et al 2014b )

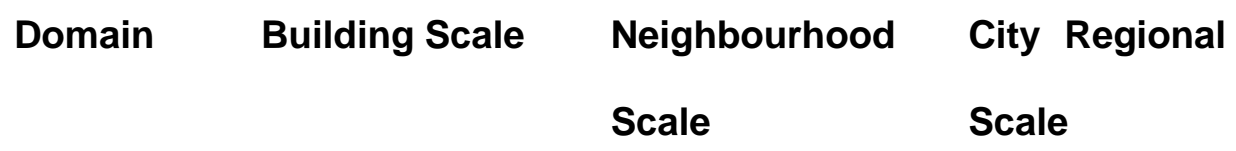

\section{Building}

Fabric

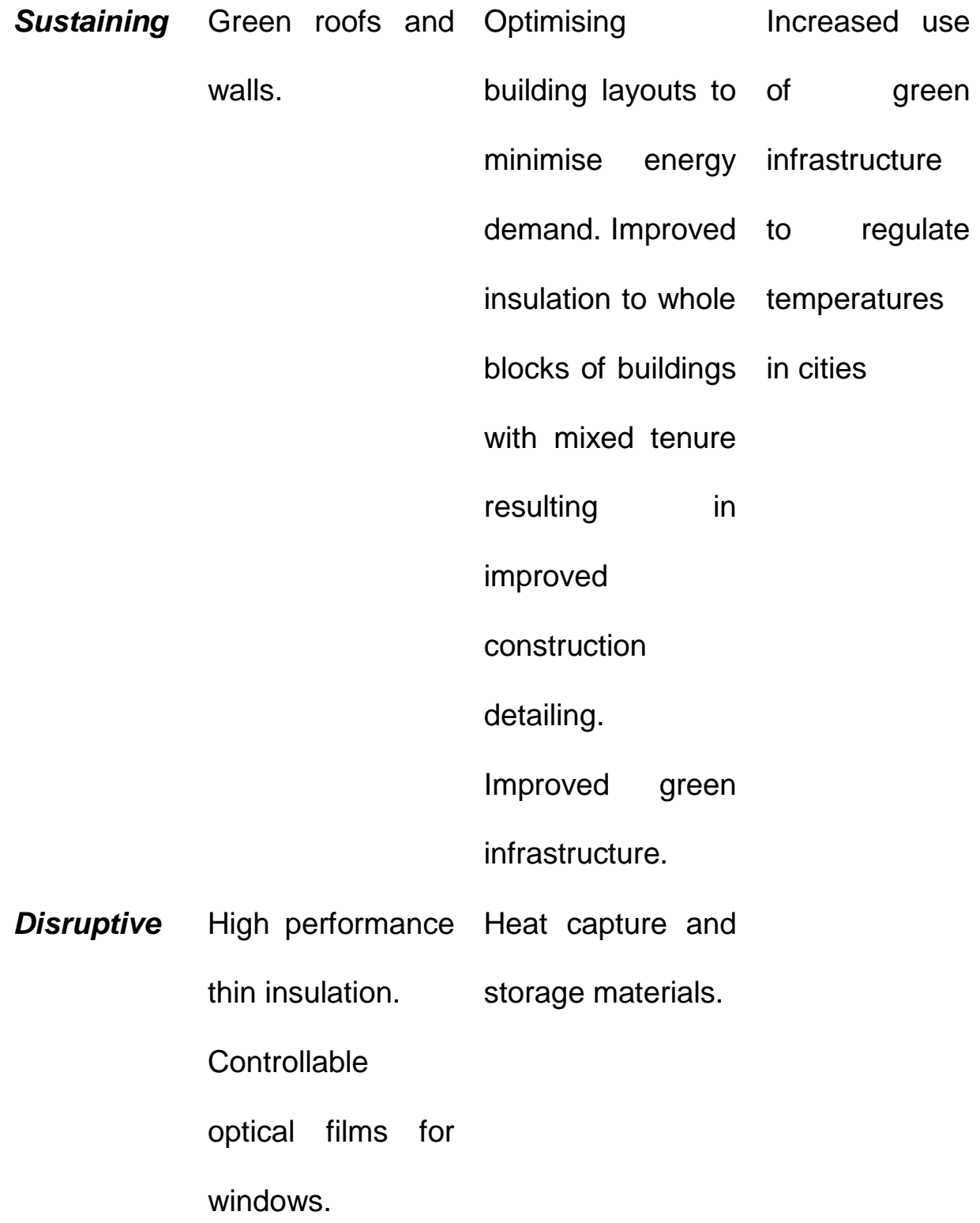


Modular

construction.

Phase change

materials.

\section{Building}

Services

Sustaining PVs, ground PVs, community PVs, waste to source heat district heating energy heat

pumps, solar and CHP. and steam

thermal. Greater Anaerobic systems, CHP

efficiency of digestion and and district

plant/equipment micro-generation heating

and more intuitive schemes.

systems and Smart grid

controls. technology.

Smart meters and Large scale

micro CHP. district heating

and CHP.

Hydrogen

Disruptive LED lighting. networks. LED lighting in 
Note to Table 1: PV-photovoltaic: LED-light emitting diode; CHP-combined heat and power.

Interestingly this research found that the more 'closed' nature of the online survey meant a wider range of disruptive energy technologies were identified by respondents than in the more 'open' workshops, where perhaps conformity and consensual discussion 'shut down' more innovative ideas. The results from the survey and workshops were also integrated and linked back to the socio-technical context of the urban retrofit 'city visions', which were anchored in the MLP framework. For example, the smart networked city was characterised by novel materials and products which underpinned an 'electric future'. In this scenario, despite end-use efficiency improvements and widespread diffusion of integrated renewable technologies in buildings, overall energy use remains high. Electrification of heat and transport could therefore mean significant increases in electricity demand. Alongside the role out of smart grids and appliances, this future envisages widespread application of novel and disruptive materials and products (for example, vacuum panel insulation and phase change materials) to improve the energy performance of existing buildings. The deployment of sustaining micro-generation and renewable technologies (for example, heat pumps, PV) is also primarily at building scale (Eames et al, 2014a).

The compact city vision was characterised by community-level and city-wide heat and power networks. Here, sustaining and distributed micro-generation (for example, fuel cell CHP) and renewables (for example, solar thermal, PV, and heat pumps) are deployed with more disruptive community and city scale heat and power networks (for example, industrial heat). Walking, cycling and low carbon mass transit systems (a sustaining innovation), also contribute to significant reductions in transport energy use.

Ultimately this work also helped shape the city -specific urban retrofit visions for Cardiff in the research. for example, the 'Connected Cardiff' vision envisages substantial private investment in building sustaining integrated renewables (including PV), and with substantial growth in more disruptive decentralised energy systems (Eames et al, 2014).

\subsection{Lessons learned and discussion}

Transitions theory and the MLP offer a valuable way of assessing and analysing major sociotechnical change. However, the complexity of cities, the 'locked in' nature of the built environment, and related 'sunk' costs all provide major challenges for managing a sustainable transition (Eames et al 2017). Although visioning can help us understand a variety of technological innovations and social innovations, when we 'open up' the debate and discussion about visions, detailed information and views about technological innovation may be lost or missed out. For specific technology impacts to be examined accurately, they must be categorised across scales and sectors (i.e. energy, water, and waste and resource use) but their disruptive potential also needs analysis.

Nonetheless, it should also be appreciated that categorising 'disruptive' and 'sustaining' technologies may be open to some degree of controversy (King and Baatartogtokh, 2015) - for example, over time, as some technologies become more commonplace, and particularly at the 'high end' of sustaining technologies, there may be a blurring of this distinction (Wilson, 2017): it follows that what may be disruptive today may, later in time, be considered sustaining in the medium and longer term. Moreover, what is disruptive for one group of stakeholders may be 
sustaining for another group, depending on functionality and familiarity of the technology (Nagy et al, 2016).

More often than not, however, work on energy innovation in government and industry occurs in a vacuum with little or no attention paid to the wider socio-technical processes at work. For example, the Technology Needs Assessment (TINA) of UK non-domestic buildings aims to identify and value the key innovation needs of the sector in order to prioritise public sector investment in low carbon innovation (Carbon Trust, 2012). In the TINA report, 'innovative measures' are described as 'integrated design', 'build process', 'management and operation' and 'materials and components', but these are not differentiated between disruptive and sustaining technologies, making it difficult to assess the true impact of such innovations. Similarly, recent work by PwC (PwC, 2016) has identified eight 'disruptive energy technologies' including electric vehicles, distributed generation, and microgrids, but again little or no attempt is placed on positioning these within a specific socio-technical context, although scenarios are deployed.

The consideration of disruptive (and sustaining) energy (and water and waste) technologies also requires an understanding of the policy and institutional arrangements which are part of the socio-technical framework, and which relate to both the 'landscape' and the 'regime' in the MLP. This also raises further issues about the critical challenges faced in retrofitting cities at scale (Eames et al, 2014b). Firstly, creating an inclusive retrofit agenda for a city must recognise the conflicting rationales and framings of a range of stakeholders to find solutions which can work successfully in different urban contexts. Secondly, this requires the creation of specific city visions which do recognise the socio-technical context of disruptive technologies. Thirdly, in policy terms, this also means developing the institutional capacity and aggregated decisionmaking to be able to scale up change across city level and to develop innovative financial and social innovation models to help underpin the transition (Eames et al, 2014b; Alexander, 2014).

Urban foresight therefore offers us key advantages for thinking about the future of cities (Eames et al, 2017). Firstly, a variety of plausible and coherent future visions can be assessed through participatory processes. Secondly, a wide range of stakeholder engagement can produce strategies to deal with the sorts of future environmental and socio-economic change we might anticipate. Thirdly, the development of expert networks can help in underpinning knowledge exchange with a variety of stakeholders and decision-makers. As the UK Future of Cities Foresight programme points out (Government Office of Science, 2016b:7):

"City foresight is the science of thinking about the future of cities. It draws on diverse methods to give decision-makers comprehensive evidence about anticipated and possible future change. With ever increasing volumes of available data and emerging new analytical approaches, cities need to be equipped for complex decision-making about the future in a way that engages the appropriate partners and communities."

In the context of city foresight, this short perspective has used MLP and DIT to highlight the conceptualisation of urban retrofit as a socio-technical process. We have also tried to show how backcasting, visioning and roadmapping methodologies, supported by horizon scanning offer powerful ways to explore futures in urban retrofit, and that understanding disruptive energy innovation is an important part of this. In our view, the integrated methodological framework described here offers a pragmatic way to engage with a range of key stakeholders to explore the socio-technical construction of urban retrofit processes, including disruptive energy innovations, across a variety of scales and domains. 
Acknowledgments: Our thanks go to the referees for their helpful comments. We would also like to acknowledge the support of EPSRC (Grant Number EP/1002162/1) in funding the work on which much of this perspective is based. Further information on the programme of research can be found at www.retrofit2050.org.uk 


\section{References}

Alexander, 2. (2014) Disruptive Social Innovation for a Low Carbon World. Visions and Pathways 2040 Project Paper (Accessed September 2017: http://www.visionsandpathways.com/wpcontent/uploads/2014/05/Alexander_Disruptive-Innovation_290514.pdf)

Arundel, A., Kanerva, M. and Kemp, R. (2011) Integrated Innovation Policy for an Integrated Problem: Addressing Climate Change, Resource Scarcity and Demographic Change to 2030. PRO INNO Europe: INNO-Grips II report Brussels: European Commission, DG Enterprise and Industry.

Arup (2016) Towards the Delivery of a National Residential Energy Efficiency Programme. Arup, London. (Accessed September 2017 at: https://www.retrofitacademy.org/2016/05/18/arup-publish-residentialretrofit-report/)

Better Buildings Partnership. (2010) Low Carbon Retrofit Toolkit: A Roadmap to Success. London: BBP. (Accessed September 2017 at: http://www.betterbuildingspartnership.co.uk/low-carbon-retrofit-toolkit) Bower, B J.L., and Christensen, C., (1995) Disruptive Technologies: Catching the Wave, Harvard Business Review, January-February (1995) pp 43-53.

Busnelli, G., Shantaram,V. and Vatta, A. (2011) Battle for the home of the future: how utilities can win, McKinsey Quarterly (Sustainability and Resource Productivity), Summer, pp 44-53.

Carbon Trust (2012) Technology Innovation Needs Assessment (TINA). Non-Domestic Buildings Summary Report. (Accessed September 2017 at: https://www.carbontrust.com/our-clients/n/non-domesticbuildings-tina/)

Christensen, C. (2003) The innovator's solution: creating and sustaining successful growth Harvard Business Press.

Dawson, R. (2007) Re-engineering cities: a framework for adaptation to global change, Phil. Trans. R. Soc. A., 365, 3085-3098

Dixon, T. (2009) Urban Land and Property Ownership Patterns in the UK: Trends and Forces for Change. Land Use Policy, 26, Supplement 1, S43-S53.

Dixon, T. (2014) What does "retrofit" mean, and how can we scale up action in the UK sector? Journal of Property Investment and Finance, 32 (4). pp. 443-452

Dixon, T., Eames, M., Hunt, M. and Lannon, S., eds. (2014a) Urban retrofitting for sustainability: mapping the transition to 2050. Routledge. ISBN 9780415642514

Dixon, T., Eames, M., Britnell, J., Watson, G. B. and Hunt, M. (2014b) Urban retrofitting: identifying disruptive and sustaining technologies using performative and foresight techniques. Technological Forecasting \& Social Change, 89. pp. 131-144

Eames, M. (2011) Developing Urban Retrofit Scenarios: An Outline Framework for Scenario Foresight and Appraisal. Retrofit 2050 Working Paper WP 2011/4 (Accessed September 2017 at: http://www.retrofit2050.org.uk/working papers) 
Eames, M., De Laurentis, C., Hunt, M., Lannon, S. and Dixon, T., (2014a) Cardiff 2050: City regional scenarios for urban sustainability. Project Report. Cardiff University, Cardiff. ISBN 9781899895168

Eames, M., Dixon, T., Lannon, S., Hunt, M., De Laurentis, C., Marvin, S., Hodson, M., Guthrie, P. and Georgiadou, M. C., (2014b) Retrofit 2050: Critical challenges for urban transitions. Technical Report. Cardiff University, Cardiff. ISBN 9781899895120

Eames, M., Dixon, T., Hunt, M. and Lannon, S., eds. (2017) Retrofitting cities for tomorrow's world. Wiley-Blackwell, Oxford, pp288. ISBN 9781119007210 (In Press)

Eames, M., Dixon, T., May, T. and Hunt, M. (2013) City futures: exploring urban retrofit and sustainable transitions. Building Research and Information, 41 (5). pp. 504-516

Eames, M., Hunt, M., Dixon, T. and Britnell, J. (2013b) Retrofit city futures: visions for urban sustainability. Retrofit 2050 Report ISBN 978-1-899895-12-0

Elzen, B., Geels, F.W. and Green, K. (2004). Transitions to Sustainability: Lessons Learned and Remaining Challenges, in Elzen, B., Geels, F.W. and Green, K. (eds.). System Innovation and the Transition To Sustainability. Cheltenham: Edward Elgar, 282-300.

Foxon, T. (2003) Inducing innovation for a low-carbon future: drivers, barriers and policies. Carbon Trust, London.

Geels, F.W., Monaghan, A., Eames, M. and Steward, F. (2008). The feasibility of systems thinking in sustainable consumption and production policy: A report to the Department for Environment, Food and Rural Affairs. Brunel University. Defra, London.

Government Office of Science (2016a) Future of Cities: The Science of Cities and Future Research Priorities - A report by the project's Lead Expert Group. GOS/Foresight, London (Accessed September 2017 at: https://www.gov.uk/government/publications/future-of-cities-science-of-cities)

Government Office of Science (2016b) Future of Cities : Foresight for Cities. GOS/Foresight, London (Accessed September 2017 at: https://www.gov.uk/government/publications/future-of-cities-foresightfor-cities)

Greenacre, P., Gross, R. and Speirs, J. (2011) Innovation Theory: A review of the Literature, ICEPT Working Paper, Imperial College, London.

Hockerts, K. and Morsing, M. (2008) A Literature Review on Corporate Social Responsibility in the Innovation Process, Copenhagen Business School, Denmark.

Hodson, M., and Marvin, S. (2012) 'Mediating Low-Carbon Urban Transitions? Forms of Organisation, Knowledge and Action', European Planning Studies, 20: 3, pp.421-39.

Hodson, M., and Marvin, S., eds. (2016) Retrofitting Cities: Priorities, Governance and Experimentation. Earthscan, Routledge.

Kelly, M. (2009) Retrofitting the existing UK building stock, Building Research \& Information, 37:2, 196200 
Kemp, R., Loorbach, D. and Rotmans, J. (2006). Transition Management as a Model for Managing Processes of Co-Evolution Towards Sustainable Development. In Andersen, M.M. and Tukker, A. (eds.). Perspectives on Radical Change to Sustainable Consumption and Production (SCP), Proceedings of Workshop of the Sustainable Consumption Research Exchange (SCORE) Network, pp. 459-477.

King, A.A., and Baatartogtokh, B. (2015) How Useful is the Theory of Disruptive Innovation? MIT Sloan Management Review, Fall, 57, No 1, 77-90

Living Cities (2010) Green Cities: How Urban Sustainability Efforts Can and Must Drive America's Climate Change Policies. Living Cities.

May, T., Marvin, S., Hodson, M. and Perry, B. (2010). The SURF-Arup Framework for Urban Infrastructural Development'. SURF report published and distributed to key stakeholders at national and international levels (policy makers, universities, politicians and research councils). Available at: www.surf.salford.ac.uk

McGrail, S., and Gaziulusoy, I. (2014) Using futures inquiry to create low-carbon, resilient urban futures: A review of practice, theory and process options for the Visions and Pathways project. V \& P 2040 Working Paper (Accessed September 2017: http://www.visionsandpathways.com/research/papers/) Mulki, S. and Hinge, A. (2010) Green Investment Horizons: Effects of Policy on the Market for Building Energy Efficient Technologies, World Resources Institute, Working Paper, Washington DC.

Nagy, D., Schuessler, J., and Dubinsky, A. (2016) Defining and Identifying Disruptive Innovations, Industrial Marketing Management, Vol 57, August, 119-126

National Research Council of the National Academies (2010) Persistent Forecasting of Disruptive Technologies, Report 2 National Academies Press, Washington DC.

Parkinson, G. (2012) Why generators are terrified of solar, RE New Economy (Accessed September 2017: http://reneweconomy.com.au/2012/why-generators-are-terrified-of-solar-44279)

PwC (2016) Capturing value from disruption: Technology and innovation in an era of energy transformation (Accessed September 2017: https://www.pwc.com/gx/en/energy-utilitiesmining/pdf/capturing-value-from-disruption.pdf)

Smith, A., Vo $\beta$, J.P. and J. Grin (2010) Innovation studies and sustainability transitions: the allure of the multi-level perspective, and its challenges Research Policy 39: 435-448

Truffer, B.and Coenen, L. Environmental Innovation and Sustainability Transitions in Regional Studies, Regional Studies: The Journal of the Regional Studies Association, Volume 46, Number 1, 1 January 2012 , pp. 1-21(21)

UN (2014) World Urbanisation Prospects. United Nations, New York.

UN Habitat (2016) Sustainable Urbanization in the Paris Agreement: Comparative review of Nationally Determined Contributions for Urban Content, UN Habitat Kenya

Wilson, C. (2017). Disruptive low carbon innovations. European Council for an Energy Efficient Economy (ECEEE) Summer Study. Hyeres, France. (Accessed September 2017: http://silci.org/wpcontent/uploads/2017/07/Wilson_ECEEEpaper_FINAL_May2017.pdf) 
Yu, D. and Hang, C.C. (2010) A reflective review of Disruptive Innovation Theory, International Journal of Management Reviews, 12, 4 pp 435-452. 